\title{
Pengaruh Terapi Bekam Terhadap Penurunan Skala Nyeri Dan Peningkatan Kualitas Tidur Pada Pasien Low Back Pain (LBP)
}

Ferdiansyah Sirotujani 1, Kusbaryanto2, Falasifah Ani Yuniarti3

1 Mahasiswa Magister Keperawatan Universitas Muhammadiyah Yogyakarta

2 Dosen Fakultas Kedokteran dan Ilmu Kesehatan Universitas Muhammadiyah Yogyakarta

3 Dosen Program Studi Magister Keperawatan, Program Pascasarjana Universitas Muhammadiyah Yogyakarta

*correspondence author: Telepon : 087747934062, Email : siro.ferdiansyah@gmail.com

DOI: https://doi.org/10.33859/dksm.v10i1.453

\begin{abstract}
ABSTRAK
Latar Belakang: Bekam termasuk pengobatan yang digunakan oleh Nabi Muhammad SAW. Metode ini menggunakan gelas bertekanan negatif untuk mengeluarkan darah dari tubuh, salah satu gejala penyakit yang dapat dikurangi dengan bekam adalah low back pain.

Tujuan: Tujuan penelitian ini yaitu untuk mengetahui pengaruh terapi bekam terhadap penurunan skala nyeri dan peningkatan kualitas tidur pada pasien low back pain di wilayah kerja Puskesmas Batunyala ombok Tengah.

Metode: Penelitian ini menggunakan metode penelitian quasi experiment design dengan rancangan pre-test-post test control group design. Metode pengambilan sampel menggunakan Accidental sampling dengan sampel sebanyak 34 orang yang dibagi menjadi kelompok intervensi dan kontrol. Instrumen pengambilan data menggunakan VAS dan PSQI. Analisis univariat disajikan dalam bentuk tabel distribusi frekuensi dan analisis bivariat dengan uji paired $t$-test.

Hasil: Hasil penelitian ini menunjukkan bahwa ada perbedaan skala nyeri dan kualitas tidur sebelum dan sesudah diberikan perlakuan pada kelompok intervensi dengan $p$-value $0,000 \mathrm{p}<0,05$, tidak ada perbedaan skala nyeri dan kualitas tidur sebelum dan sesudah diberikan perlakuan pada kelompok kontrol dengan $p$-value skala nyeri 0,188 dan kualitas tidur $0,216 \mathrm{p}>0,05$. Ada pengaruh terapi bekam terhadap pengaruh terapi bekam terhadap penurunan skala nyeri dan peningkatan kualitas tidur pada pasien low back pain di wilayah kerja Puskesmas Batunyala Lombok Tengah dengan nilai $p$ value $0,000 \mathrm{p}<0,05$.
\end{abstract}

Kata Kunci : Terapi bekam, Skala Nyeri, Kualitas Tidur 


\title{
Effects of Cupping Therapy on Decreasing Pain Scale and Improving Sleep Quality in Low Back Pain (LBP) Patients
}

\begin{abstract}
Bacground: Cupping is a treatment used by the Prophet Muhammad. This method uses a negative pressure glass to remove blood from the body, one of the symptoms that can be reduced by cupping is low back pain.

Aim:The purpose of this study is to analyze the influence of cupping therapy to decrease the pain scale and increase the sleep quality in low back pain patient at Puskesmas Btunyala Lombok Tengah.

Method: This study used a quasy-experiment research design with pre-test-post-test control group design. Accidental sampling method was used to get the samples of 34 people, divided into intervention and control groups. The data instrument used the VAS and PSQI. Univariat analysis was presented in frequency distribution table and bivariate analysis used paired t-test.

Result: The results of this study indicated that there was a difference of pain scale and sleep quality in the low back pain patient before and after being given the treatment in the intervention group with p-value 0,001 p<0,05, there was no difference of pain scale and sleep quality in the low back pain patient before and after being given the treatment in the control group with p-value 0,118 for pain scale and 0,216 for sleep quality $p>0,05$.There was an influence of of cupping therapy to decrease the pain scale and increase the sleep quality in low back pain patient at Puskesmas Batunyala Lombok Tengah.with $p$-value of $0.001<\alpha(0.05)$.

Cupping therapy can be used as an alternative intervention for managing low back pain.
\end{abstract}

Keywords : Cupping Therapy, Pain Scale, Sleep Quality

\section{Pendahuluan}

The International Association for the Study of Pain (IASP) menyatakan yang termasuk dalam low back pain adalah nyeri yang dibatasi daerah superior oleh garis transversal imajiner yang melalui ujung processus spinosus dari vertebra thorakal teakhir, daerah inferior garis transversal imajiner yang melalui ujung processus spinosus dari vertebra sakralis pertama dan lateral oleh garis vertikal yang di tarik dari batas lateral spina lumbalis (Guyton, 2006).

Low back pain secara spesifik bukan penyakit, melainkan adalah sebuah gejala yang mungkin disebabkan oleh berbagai proses yang berbeda. Low back pain biasanya digambarkan sebagai rasa tidak nyaman didaerah lumbosakralis pada bagian belakang yang menjalar atau tidak ke bagian kaki, pinggul dan bokong (Romy et al., 2012). 
Dinamika Kesehatan Jurnal Kebidanan dan Keperawatan Vol 10 No. 1 Juli 2019 (ISSN: 2086-3454 EISSN: 2549-4058)

url: http://ojs.dinamikakesehatan.unism.ac.id DOI : https://doi.org/10.33859/dksm.v10i1

Pengaruh Terapi Bekam Terhadap Penurunan Skala Nyeri dan Peningkatan Kualitas Tidur pada Pasien Low Back Pain (LBP)

Prevalensi terjadinya low back pain di

Amerika Serikat adalah sekitar 60\%-80\%. Dari

semua kejadian low back pain tersebut $70 \%$

disebabkan oleh peregangan otot atau keseleo,

$10 \%$ karena proses degeneratif tulang vertebra,

4\% karena penyempitan discus

intervertebralis (DIV), 4\% disebabkan oleh

fraktur kompresi osteoporosis dan 3\%

disebabkan oleh stenosis tulang belakang.

Penyebab lainnya hanya sekitar $1 \%$ (Hills, 2014).

Prevalensi penyakit muskuloskeletal di Indonesia berdasarkan pernah didiagnosis oleh tenaga kesehatan yaitu 11,9 persen dan berdasarkan diagnosis atau gejala yaitu 24,7 persen sedangkan di provinsi NTB angka prevalensi penyakit pada sistem otot dan jaringan pengikat di puskesmas pada tahun 2015 sebanyak 122,737 kasus dan meningkat menjadi 129,044 pada tahun 2016. Berdasarkan data tersebut terdapat peningkatan signifikan. Selain itu perilaku masyarakat yang tidak sehat masih menjadi faktor utama disamping lingkungan, pelayanan kesehatan dan pekerjaan (KemenkesNTB, 2016).

Prevalensi penyakit musculoskeletal tertinggi berdasarkan pekerjaan adalah pada petani, nelayan atau buruh yaitu 31,2 persen. Prevalensi meningkat terus menerus dan mencapai puncaknya antara usia 35 hingga 55 tahun. Semakin bertambahnya usia seseorang, risiko untuk menderita low back pain akan semakin meningkat karena terjadinya kelainan pada diskus intervertebralis. (RISKESDAS, 2013). Diantara efek yang ditimbulkan low back pain adalah menurunnya kualitas tidur yang diakibatkan oleh nyeri pada punggung bagian bawah (Kovacs et al., 2018).

Menurunnya kualitas tidur bisa disebabkan oleh peningkatan nyeri dari pasien low back pain (Marty et al., 2008). Berdasarkan hasil penelitian yang telah dilakukan oleh Nourma (2015) terdapat hubungan bermakna antara skala nyeri pada pasien low back pain dengan kualitas tidur.

Berdasarkan uraian penelitian diatas dapat disimpulkan bahwa antara nyeri dan kualitas tidur adalah faktor resiko yang 
diakibatkan oleh low back pain dan saling berhubungan sebagai tanda dan gejala sehingga harus ditangani dengan tepat baik dengan cara terapi farmakologi maupun non farmakologi.

Terapi terhadap nyeri dan kualitas tidur dapat dilakukan dengan beberapa cara seperti terapi farmakologi, non farmakologi, dan terapi komplementer. Terapi farmakologi meliputi obat anti ansietas dan obat anti depresi dan untuk nyeri dengan pemberian analgetik berupa obat anti inflamasi non steroid (NSAID) sampai gejala menghilang yang sesuai dari advis dokter, sedangkan untuk terapi non farmakologi meliputi terapi pembatasan tidur, terapi control stimulus, terapi pencatatan waktu tidur (sleep diary), serta terapi komplementer meliputi pengobatan herbal, terapi teknik relaksasi (nafas dalam, progresif, meditasi, yoga, hipnotis), pijat refleksi, terapi medan magnet, serta terapi bekam dan akupuntur.

Pada pasien low back pain sekitar 80-90\% dari mereka menyatakan tidak melakukan usaha apapun ketika gejala low back pain itu timbul. Dengan kata lain, hanya 10-20\% penderita low back pain yang pergi ke perawatan medis atau ke pelayanan kesehatan (Kreshnanda, 2016). Namun saat ini banyak yang sudah meninggalkan medis dan beralih ke pengobatan komplementer. Frekuensi dari kebermanfaatan terapi komplementer telah berkembang pesat didunia. Terapi bekam merupakan salah satu terapi komplementer untuk menurunkan skala nyeri dan meningkatkan kualitas tidur pada pasien low back pain, yang dapat diterapkan sebagai salah satu penatalaksanaannya (AlBedah et al., 2015).

Menurut teori taibah, efek terapi bekam adalah membersihkan darah dan ruang interstitial dari substansi berbahaya, substansi penyebab pathogen, substansi penyebab nyeri, dan substansi yang berhubungan dengan nyeri. Intervensi ini setara dengan analgesik Bekam pada titik tertentu dapat menstimulasi kuat syaraf permukaan kulit yang akan dilanjutkan pada cornu posterior medulla spinalis melalui syaraf A-delta dan C, serta traktus spinothalamicus kearah thalamus yang akan 
menghasilkan endorphin. Sedangkan sebagian

rangsang lainnya akan diteruskan melalui serabut aferen simpatik menuju kemotor neuron dan menimbulkan reflek intubasi nyeri.

Bekam merupakan metode pengobatan klasik yang telah digunakan dalam mengobati berbagai kelainan penyakit seperti insomnia, hemophilia, hipertensi, gout, reumatik arthritis, sciatica, back pain (sakit punggung), migraine, vertigo, anxietas (kecemasan) serta penyakit umum lainnya baik bersifat fisik maupun mental (Ridho, 2015).

\section{Metode}

Penelitian ini menggunakan metode quasy experiment pre and post test with control group. Penelitian dilakukan mulai bulan Agustus hingga bulan September 2018. Tehnik pengambilan sampel menggunakan tehnik accidental sampling, instrumen yang digunakan untuk menilai skala nyeri dan kuaitas tidur menggunakan VAS dan PSQI, dan jumlah responden pada penelitian ini sebanyak 34 responden.

Kriteria inklusi pada penelitian ini adalah pasien dengan low back pain yang sedang atau pernah datang ke Puskesmas untuk berobat, pasien low back pain karena mekanik peregangan otot/muscle strain, Umur responden antara 30-60 tahun, nyeri ringansedang.

Hasil uji normalitas data menggunakan uji Shapiro wilks didapatkan nilai P Value > 0.05 pada nilai skala nyeri dan kualitas tidur baik pada saat pre-test maupun post test sehingga dapat diambil kesimpulan data berdistribusi normal. Metode analisa pada penelitian ini menggunakan uji statistik parametrik yaitu dengan menggunakan uji paired t test.

\section{Hasil}

Tabel.1 Karakteristik Responden

\begin{tabular}{|c|c|c|c|c|c|c|}
\hline \multirow[t]{2}{*}{ Variabel } & \multicolumn{2}{|c|}{ Intervensi } & \multicolumn{2}{|c|}{ Kontrol } & \multirow[t]{2}{*}{ Total } & \multirow[t]{2}{*}{$\%$} \\
\hline & $\mathbf{F}$ & $\%$ & $\mathbf{F}$ & $\%$ & & \\
\hline \multicolumn{7}{|l|}{ Usia } \\
\hline $\begin{array}{l}\text { 36-45 Tahun } \\
\text { (Dewasa Akhir) }\end{array}$ & 5 & 29.4 & 8 & 47.1 & 13 & 38.2 \\
\hline $\begin{array}{l}\text { 46-55 Tahun } \\
\text { (Lansia Awal) }\end{array}$ & 10 & 58.8 & 7 & 41.2 & 17 & 50.0 \\
\hline $\begin{array}{l}\text { 56-65 Tahun } \\
\text { (Lansia Akhir) }\end{array}$ & 2 & 1.8 & 2 & 11.8 & 4 & 11.8 \\
\hline Total & & & & & 34 & 100 \\
\hline P Value & & & & 0.116 & & \\
\hline \multicolumn{7}{|l|}{ Pendidikan } \\
\hline Tidak sekolah & 3 & 17.8 & 4 & 23.5 & 6 & 20.6 \\
\hline $\mathrm{SD}$ & 2 & 11.8 & 4 & 23.5 & 7 & 17.6 \\
\hline SMP & 4 & 23.5 & 4 & 23.5 & 8 & 23.5 \\
\hline SMA & 8 & 47.1 & 5 & 29.4 & 13 & 38.2 \\
\hline Total & & & & & 34 & 100 \\
\hline P Value & & & & 0.508 & & \\
\hline \multicolumn{7}{|l|}{ Pekerjaan } \\
\hline Petani & 11 & 64.7 & 10 & 58.8 & 21 & 61.8 \\
\hline Buruh & 6 & 35.3 & 7 & 41.2 & 13 & 38.2 \\
\hline Total & & & & & 34 & 100 \\
\hline P Value & & & & 0.685 & & \\
\hline
\end{tabular}

Berdasarkan tabel 1 rata-rata sebagian

besar usia responden berada di rentang usia 46- 
55 tahun sejumlah 17 responden (50.0Tingkat

pendidikan responden terbanyak adalah

setingkat SMA sederajat sejumlah 38

responden (38.2\%). Pekerjaan responden

sebagian besar adalah petani sejumlah 21

responden $(61.8 \%)$.

Tabel 2. Perbedaan Skala Nyeri dan Kualitas Tidur Sesudah Diberikan Terapi Bekam antara Kelompok Intervensi dan Kontrol pada Pasien Low Back

\begin{tabular}{|c|c|c|c|c|c|c|}
\hline Variabel & Kelompok & $\mathbf{N}$ & Mean & SD & $\mathbf{t}$ & $\begin{array}{c}p- \\
\text { value }\end{array}$ \\
\hline \multirow[t]{2}{*}{ Skala Nyeri } & Intervensi & 17 & 2.70 & 1.04 & -4.58 & 0,01 \\
\hline & Kontrol & 17 & 4.41 & 1.12 & & \\
\hline Kualitas & Intervensi & 17 & 6.41 & 1.84 & - & 0.01 \\
\hline tidur & Kontrol & 17 & 8.70 & 1.72 & 3.790 & \\
\hline
\end{tabular}

Berdasarkan tabel 2 didapatkan nilai $\mathrm{P}$ Value sebesar $0.001 \quad(\mathrm{P}<0.00)$ untuk skala nyeri dan kualitas tidur sehingga dapat disimpulkan terdapat perbedaan skala nyeri dan kualitas tidur sebelum dan sesudah diberikan terapi bekam pada pasien low back pain di wilayah kerja Puskesmas Batunyala, Lombok Tengah.

\section{Pembahasan}

A. Karaketristik Responden

1. Usia

Pada penelitian ini, responden didominasi oleh responden dengan usia 46-
55 tahun (lansia awal). Hal ini sejalan dengan penelitian yang dilakukan oleh Ahda (2017) yang menyatakan bahwa pasien yang menderita low back pain ratarata berusia diatas 50 tahun. Demikian juga dengan penelitian yang dilakukan oleh Cahyono (2015) mayoritas penderita low back pain pada penelitian tersebut adalah usia 49-69 tahun.

Muheri (2010) menyatakan semakin bertambahnya umur maka akan terjadi penurunan fungsi sistem tubuh manusia yang salah satunya adalah sistem muskuloskeletal. Hal ini akan berakibat pada meningkatnya keluhan muskuloskeletal yang di dalamnya termasuk keluhan nyeri punggung bawah.

Low back pain merupakan keluhan yang berkaitan erat dengan umur. Hal ini mungkin berhubungan dengan beberapa faktor etiologi tertentu yang lebih sering dijumpai pada umur yang lebih tua. Bahkan keluhan low back pain ini semakin lama semakin meningkat hingga umur sekitar 55 tahun. 
2. Pendidikan

Pada penelitian ini mayoritas responden adalah lulusan SMA sederajat sebanyak 13 responden. Hal ini sajalan dengan penelitian yang dilakukan oleh septanida (2014) yang berjudul nyeri punggung bawah dan faktor-faktor risiko yang mempengaruhinya mayoritas pendidikan responden adalah SMA sebanyak 25 responden $(63,6)$.

Menurut Notoatmodjo (2010) mengatakan jika tingkat pendidikan seseorang dapat mempengaruhi kemampuan seseorang untuk menerima sebuah informasi dan mengolahnya sebelum menjadi sebuah perilaku yang baik maupun buruk sehingga dapat berdampak terhadap status kesehatannya. Menurut peneliti tingkat pendidikan yang tinggi tidak menjamin orang akan terhindar dari penyakit. Kemungkinan yang menyebabkan terjadinya low back pain adalah dari faktor-faktor lain. Faktorfaktor yang menyebabkan terjadinya fenomena ini kemungkinan yang dominan adalah faktor pola hidup yang tidak baik, penyakit kronis dan proses menua.

\section{Pekerjaan}

Pada penelitian ini mayoritas pekerjaan responden adalah petani sebanyak 21 responden. Hal ini sejalan dengan penelitian Phetcarat (2014) yang mana tujuan penelitiannya adalah untuk mengetahui prevalensi kejadian nyeri low back pain pada petani saat pemindahan padi dengan responden sebanyak 344 responden. Pada penelitian ini menunjukkan prevalensi terjadinya low back pain pada petani adalah $83,1 \%$ hal ini berhubungan dengan durasi kerja lebih atau kurang dari enam hari kerja.

Pekerjaan petani memerlukan tenaga yang ekstra serta berhubungan dengan posisi tubuh ketika bekerja hal ini sejalan dengan penelitian Sitepu (2015) yang menyatakan bahwa pekerjaan petani berkaitan dengan posisi tubuh seperti mengangkat, membungkuk atau memindahkan hasil panen dan kegiatan tersebut dilakukan secara terus menerus 
dalam jangka waktu yang lama hal ini

mengakibatkan keluhan subyektif pada pinggan petani.

Menurut peneliti, kejadian low back pain terjadi juga karena faktor durasi kerja dan faktor stress.

B. Pengaruh Terapi Bekam terhadap Skala Nyeri dan Kualitas Tidur pada pasien Low Back Pain

Berdasarkan hasil penelitian, dari 34 responden rata-rata skor skala nyerinya menurun. Hal ini membuktikan bahwa terapi bekam secara ilmiah dapat menurunkan skala nyeri secara berkala.

Perubahan skala nyeri ini disebabkan oleh banyaknya opiat endogen dalam tubuh yang pengeluarannya distimulasi oleh bekam. Seperti yang telah dibahas bahwa low back pain yang diderita pasien sebenarnya sudah ditangani oleh tubuh, hanya telah melewati batas ambang nyeri. Terapi bekam akan menimbulkan stimulasi nyeri yang baru sehingga akan meningkatkan produksi opiat endogen.

Opiat endogen merupakan hasil dari stimulasi nyeri pada bagian per iaqueductal gray matter, spesific nuclei di medulla, dan reticular formation. Ketiga regio inilah yang membentuk sistem analgetik dalam tubuh atau dikenal sebagai descending analgetic pathway. Stimulasi pada per iaqueductal gray matter akan direspon oleh spesific nuclei di medulla dan reticular formation. Kemudian impuls akan dilanjutkan melalui inhibitory interneurons di kornu dorsalis medula spinalis. Di bagian inilah dihasilkan opiat endogen seperti endorfin, enkefalin, dan dinorfin yang akhirnya akan dilepas ke ujung saraf aferen.

Opiat endogen ini akan berikatan dengan reseptor opiat dan akan menghambat pengeluaran substansi $\mathrm{P}$ sehingga hal ini akan menghambat transmisi impuls nyeri sepanjang ascending pain pathways. Sehingga dapat disimpulkan nyeri punggung bawah tidak spesifik pada pasien ditekan oleh adanya opiat endogen seperti endhorpin.

Endhorpin ini yang akan memberikan efek relaksasi dan kesegaran pada seluruh 
Dinamika Kesehatan Jurnal Kebidanan dan Keperawatan Vol 10 No. 1 Juli 2019 (ISSN: 2086-3454 EISSN: 2549-4058)

url: http://ojs.dinamikakesehatan.unism.ac.id DOI : https://doi.org/10.33859/dksm.v10i1

Pengaruh Terapi Bekam Terhadap Penurunan Skala Nyeri dan Peningkatan Kualitas Tidur pada Pasien Low Back Pain (LBP)

anggota tubuh dan posisi rileks inilah yang

menurunkan stimulus ke sistem aktivasi

reticular (SAR), dimana (SAR) yang

berlokasi pada batang otak teratas yang

dapat mempertahankan kewaspadaan dan

terjaga. Dengan demikian akan diambil

alih oleh batang otak yang lain yang

disebut bulbar synchronizing region

(BSR) yang fungsinya berkebalikan

dengan SAR, sehingga bisa menyebabkan

tidur yang diharapkan akan dapat

meningkatkan kualitas tidur.

Pada akhir terapi bekam menunjukan bahwa setelah dilakukan terapi bekam 1

kali dengan 1 kali post test dihari berikutnya selama 1 bulan didapatkan hasil bahwa terdapat peningkatan pemenuhan kebutuham tidur responden baik tidur siang dan malam. Sesuai dengan hasil penelitian bahwa peningkatan kualitas peningkatan pemenuhan kebutuhan tidur responden ini meningkat. Sebagian besar responden tertarik dengan terapi bekam ini, responden mengatakan bahwa setelah di bekam badan nyaman dan ringan. Hal ini dikarenakan bekam ini menstimulasi saraf dimana pada titik bekam yang merupakan meridian adalah daerah-daerah yang banyak mengandung banyak mioglobin.

Jaringan di sekitar titik bekam juga memiliki sel mast yang banyak dan juga serabut saraf pleksus. Semua ini faktor yang membuat titik bekam lebih sensitif terhadap rangsangan. Sehingga bekam disini memiliki efek terhadap mikrosirkulasi pembuluh darah yang nantinya akan dapat menurunkan lelah otot yang kaku sehingga berpengaruh terhadap tidur seseorang.

Terapi bekam membantu merelaksasikan tubuh sehingga dengan relaksasi ini dapat memberikan rasa nyaman untuk memenuhi kebutuhan tidur. Dalam kondisi rileks yang sempurna seluruh sel dalam tubuh akan mengalami reproduksi, penyembuhan alami berlangsung, produksi hormon tubuh diseimbangkan dan pikiran mengalami penyegaran. Sehingga dapat 
meningkatkan pemenuhan kebutuhan

tidur.

Hasil penelitian di atas sesuai dengan hasil penelitian yang dilakukan oleh Monikasari (2014) dengan judul "Pengaruh Terapi Bekam Terhadap Pemenuhan Kebutuhan Tidur Lansia Yang Mengalami Insomnia Di Posyandu Lansia Desa Sukorambi Kecamatan Sukorambi Kabupaten Jember", memberikan kesimpulan bahwa ada pengaruh terapi bekam terhadap pemenuhan kebutuhan lansia yang mengalami insomnia.

Ridho (2015) menambahkan bahwa bekam pada titik tertentu dapat menstimulasi kuat syaraf permukaan kulit yang akan dilanjutkan pada cornu posterior medulla spinalis melalui syaraf A-delta dan $\mathrm{C}, \quad$ serta traktus spinothalamicus ke arah thalamus yang akan menghasilkan endorphin. Sedangkan sebagian rangsang lainnya akan diteruskan melalui serabut aferen simpatik menuju ke motor neuron dan menimbulkan reflek intubasi nyeri. Bekam merupakan metode pengobatan klasik yang telah digunakan dalam mengobati berbagai kelainan penyakit seperti insomnia, hemophilia, hipertensi, gout, reumatik arthritis, sciatica, back pain (sakit punggung), migraine, vertigo, anxietas (kecemasan) serta penyakit umum lainnya baik bersifat fisik maupun mental.

Bekam merupakan salah satu cara detoksifikasi yang sangat berkesan dan tidak ada efek samping. Oleh karena itu, metode ini sangat dikenal dan dianjurkan sejak zaman Rosulullah Shallallahualaihiwasalam hingga saat ini, yang dikenal dengan al-hijamah atau bekam. Perkembangan sains dan teknologi menjadikan cara pengobatan ini lebih praktis, efektif dan higienis serta mengikuti kaidah-kaidah yang telah diilmiahkan, sehingga memudahkan setiap orang untuk melakukan terapi ini. 


\section{Kesimpulan}

Terdapat perbedaan skala nyeri dan kualitas tidur sebelum dan sesudah diberikan terapi bekam dengan $\mathrm{P}$ Value $0.000(\mathrm{P}<0.05)$ sehingga dapat disimpulkan terdapat pengaruh terapi bekam terhadap penurtunan skala nyeri dan peningkatan kualitas tidur pada pasien low back pain di Wilayah Kerja Puskesmas Batunyaa Lombok Tengah.

\section{Ucapan Terima Kasih}

Terima kasih kepada Universitas Muhammadiyah Yogyakarta dan Puskesmas Batunyala, Lombok Tengah yang telah memberikan ijin penelitian beserta dosen dan tim peneliti yang ikut mencurahkan waktu dan tenaga untuk penelitian ini.

\section{DAFTAR PUSTAKA}

Alsaadi, S.M., McAuley, J.H. Hush, J.M., Maher, C.G. (2011). Prevalence of Sleep Disturbance in Patients with Low Back Pain. Eur Spine J; 20: 737-743.

Andrei Calin, and Andrei Calin, Fast Facts: Low Back Pain (Health Press, 2012 $<$ http://www.fastfacts.com/_files/sampl efiles/ff_lbp2e_sample.pdf $>$ [accessed 26 December 2016]
Casazza, Brian A., 2012. 'Diagnosis and Treatment of Acute Low Back Pain', American Family Physician, 85, 343

El Sayed, S. M., Al-quliti, A. S., Mahmoud, H. S., Baghdadi, H., Maria, R. A., Nabo, M. M., et al. 2014. Therapeutic Benefits of Alhijamah: in Light of Modern Medicine and Prophetic Medicine. American Journal of Medical and Biological Research, 2(2), $46-71$

O’Donoghue, G., Fox, N., Heneghan, C., \& Hurley, D.A.. 2009. Objective and Subjective Assessment of Sleep in Chronic Low Back Pain Patients Compared with Healthy Age and Gender Matched Controls: A Pilot Study. BMC Musculoskeletal Disorders; 10: 122

Farhad, K, Schwebel, DC, Saeb, M. Elsevier.(2012). Complementary Therapies in Medicine. The effectiveness of wet-cupping for nonspecific low back pain in Iran: A randomized controlled trial. [Online] Januari 2009.[Cited: Agustus 7, 2012.] http: // www. Complementary therapies in medicine .com / article /S09652299\%2808\%2900063 -0 /abstract.

Guyton A.C. and J.E. Hall.2007. Buku Ajar Fisiologi Kedokteran. Edisi 9. Jakarta: EGC

HR Ahmad V/9,15,19, Al-Hakim IV/208 dari Samurah Radhiyallahu 'anhu. Lihat Shahiih Al-Jaami' ish Shaghiir no. 3323, Silsilah Al-Ahaadiits Ash-Shahiihah no. 1053.

HR At-Tirmidzi no. 2052, Shahiih Sunan AtTirmidizi II/204 no. 1672

Jong-in et.al. 2011.Cupping for treating pain: A systematic Review. Evidence Based Complementary and Alternative medicine volume 2001, Article ID 467014, 7 pages doi:10.1093/ecam/nep035। 
Julia J. Hill and Jennifer L. Keating. 2014. Daily Exercises and Education for Preventing Low Back Pain in Children: A Cluster Randomized. PHYS THER. Published online December 11, 2014 doi: 10.2522/ptj.20140273

KEMENKESNTB. 2017. Profil Kesehatan Masyarakat NTB. www. depkes.go.id /resources/download/profil/PROFIL_K ES.../18_NTB_2016.pdf

Lauche, Romy, Holger Cramer, Claudia Hohmann, Kyung-Eun Choi, Thomas Rampp, Felix Joyonto Saha, and others, 'The Effect of Traditional Cupping on Pain and Mechanical Thresholds in Patients with Chronic Nonspecific Neck Pain: A Randomised Controlled Pilot Study', Evidence-Based Complementary and Alternative Medicine, 2012 (2012), $1-10$

https://doi.org/10.1155/2012/429718

Low Back Pain: Priority Medicines for Europe and The World.World Health Organization [Internet]. 2013 [cited 2015 Dec 7]. Available from: www.who.int/medicines/areas/priority_ medicines/MasterDocJune28_FINA

L_Web.pdf

Martha Raile Alligood 2014 Nursing theorists and their work, edited by Martha Raile Alligood $8_{\text {th }}$ edition.USA: Elsevier

Marty, M., Rozenberg, S., Duplan, B., Thomas, P., Duquesnoy, B., Allaert, F.. 2008. Quality of Sleep in Patients with Chronic Low Back Pain. EurSpine J; 17: 839-844.

Monikasari. R. 2016. Pengaruh terapi bekam terhadap pemenuhan kebutuhan tidur lansia yang mengalami insomnia di posyandu lansia desa sukorambi kecamatan sukorambi kabupaten jember. digilib.unmuhjember.ac.id > Top > S1 - Skripsi > FIKES.

Perry \& Potter. 2010. Buku ajar Fundamental Keperawatan: Konsep, Proses, Dan praktik E/7, buku 1. Jakarta: MOSBOY.

Ramadhian, M.R., Adha, M.I.Z., 2017. Efek Analgesic Terapi Bekam Terhadap Kondisi Low Back Pain. J. Major. 6, 3943.

Ridho. A.A. 2015. Bekam sinergi: rahasia sinergi pengobatan Nabi, medis modern, traditional Chinese medicine. Solo : Aqwamedika.

Riskesdas. Laporan hasil Riset Kesehatan Dasar (RISKESDAS) Nasional. Badan Penelitian dan Pengembangan Kesehatan. Jakarta; 2013.

Sastroasmoro, S. 2010. Dasar-dasar Metodologi Penelitian Klinis Ed.3 Cet.2. Jakarta: Sagung Seto

Sharaf, A. R. (2012). Penyakit dan Terapi Bekamnya Dasar-dasar Ilmiah Terapi Bekam, penterjemah Hawin Murtadlo. Surakarta: Thibbia

Sherwood, L. 2012. Fisiologi Manusia. Penerbit Buku Kedokteran EGC, Jakarta

Susiyanto. A. 2013. Hijamah or oxidant drainage therapy (ODT) semua penyakit insyaAllah sembuh. Jakarta : Gema Insani.

Umar, Wadda, A. 2008. Sembuh dengan satu titik. Solo : Alaqwam publishing

Yuliana. Low Back Pain. Cermin Dunia Kedokteran[Internet]. 2011 [cited 2015 Dec 7]; 38(4): 273. Available from: lib.fkm.ui.ac.id/file?file=pdf/ metadata89931.pdf 